\title{
A Comparative Study of Greeting Forms Common among Native Male and Female Speakers of Persian
}

\author{
Salman Dezhara \\ Faculty of Foreign Languages, the University of Isfahan, Isfahan, 8174673441, Iran \\ Email: hamangt@hotmail.com \\ Omid Rezaei \\ Faculty of Foreign Languages, the University of Isfahan, Isfahan, 8174673441, Iran \\ Email: omidrezaei.rezaei99@gmail.com \\ Sajad Davoudi \\ Faculty of Foreign Languages, the University of Isfahan, Isfahan, 8174673441, Iran \\ Email: sajad.davoudi@gmail.com \\ Reza Soltani Kafrani \\ Faculty of Foreign Languages, the University of Isfahan, Isfahan, 8174673441, Iran \\ Email: r.soltani.k@gmail.com
}

\begin{abstract}
This study aimed at discovering the most frequent verbal behaviors associated with Persian greetings. It tried to investigate whether these behaviors vary according to relationships between interlocutors and speakers sex. The results shows that greeting forms used by Persian males and females show great differences in terms of the linguistic forms used in different situations reveling the fact that men prefer using more informal expressions and feel a greater power face in comparison to female speakers. Women mostly tend to talk about private subjects and prefer to show how they feel about the subject matter.
\end{abstract}

Index Terms - greeting forms, socio-pragmatic, interpersonal communication, formulaic and non-formulaic patterns

\section{INTRODUCTION}

It is stated by Hudson (1996) that sex is a social variable affecting one's speech, in this study this statement is tested in an Iranian context to see if it applies to Persian greeting forms or not. In so doing a sociopragmatic approach was detected to contrast greeting forms. Therefore some naturalistic contexts are used to support this hypothesis that greeting forms differ in terms of the speaker's sex. In this case two major factors of politeness and solidarity -power are taken into account to see if the forms vary in different situations or not. The results and pedagogical implications of the study are discussed.

\section{REVIEW OF LITERATURE}

Sociopragmatics refers to the way conditions of language use derive from the social situation. In other words, it involves the study of both the forms and functions of language in the given social context. The term linguistic form refers to the abstract phonological and/or grammatical characterization of language. Social functions, however, refers to the role language plays in the context of the society or the individual. For instance language is used (or functions in such a way as) to communicate ideas, express attitudes and so forth. It may also be used to identify specific sociolinguistic situations, such as informi8ty, or varieties of language, such as science or law. The term situation is generally used to refer to extra-linguistic setting in which an utterance takes place. It refers to such notions as number of participants, level of formality, nature of the on-going activities and so.

In any sociopragmatic study, therefore, two sets of categories are to be contrasted: a linguistic category and a sociological category. Grimshaw (1973) maintains that there exists a set of underlying social conventions that every speaker fallows them. One such convention is the rule that tells the speaker of a language to greet each other at the first meeting in a given social context for politeness purposes. Here the linguistic criteria are Grice's Cooperative Principle (Grice, 1975) and Leech's Politeness Maxims (Leech, 1983)

Grice's Cooperative Principle (CP) includes: 
- Quality (QL): tell the truth.

- Quantity (QN): Give the right amount of information.

- Relevance (R): Be relevant.

- Manner (M): Be clear and brief.

Leech's Politeness Maxims (PM) includes:

- Tact Maxim (TM): Minimize the cost to the other.

- Generosity Maxim (GM): Minimize the benefit to self.

- Approbation Maxim (APM): Maximize the praise of other.

- Agreement Maxim (AGM): Maximize agreement between self and other.

- Sympathy Maxim (SM): Maximize sympathy between self and other.

Closely connected to the notion of sociopragmatics is the notion of Speech Act. Speech Act is a term derived from the work of the philosopher of language, Austin, it refers to a theory which analyzes the role of utterance in relation to the behavior of the speaker and hearer in interpersonal communication. It is a community activity defined with reference to the intentions of the speaker while speaking. Several categories of speech acts have been proposed:

- directives,

- commissives,

- expressives,

- declarations,

- Representatives.

Once we begin to look at utterances from the point of view of what they do (or the speech act view point) it is possible to see any utterance as a speech act of one kind or other (that is, as having some functional value which might be quiet independent of the actual words used or their grammatical arrangements). These acts may not be as explicit or direct as out!, I do, or we leave here by seek leave to appeal, but there can be little dispute that even to say something like I saw John this morning is an act; at the simplest level it is an act of telling truth or not. There is also no reason to assume that every language has the same performatives.

We can now return to the expressions like: Nice day! How do you do? And you are looking smart today. These comprise a special kind of speech that is called "phatic communion". According to Malinowski (1923) phatic communion is a type of speech in which ties of union are created by a mere exchange of words. In such a communion words do not convey meaning. Instead, they fulfill a social function and that is their principle aim. What, for instance, is the function of apparently aimless gossip? Malinowski (1923) answers as follows:

- It consists in just this atmosphere off sociability and in the fact of the personal communion of these people. But this is in fact achieved by speech and the situation in all such cases is created by the exchange of words, by the specific feelings which form convivial gregariousness, by the give and take of utterances which make up ordinary gossip. The whole situation consists in what happens linguistically. Each utterance is an act of serving the direct binding of hearer to speaker by the tie of some social sentiment or other. Once more, language appears to us in this function not as an instrument of reflection but as a mode of action.

The verbs which are used to indicate speech act intended by the speaker are sometimes referred to as per formative verbs. The criteria which have to be satisfied in order for a speech act to be successful are known as felicity conditions. The speech event is the basic unit of analysis of spoken interaction, i.e. the emphasis is on the role of participants in constructing a discourse of verbal exchanges.

A conversation may be viewed as a series of speech act-greetings, inquiries, congratulations, comments, etc. to accomplish the work of these speech acts some organization is essential: we take turns at speaking, answer questions, mark beginning and end of a conversation and corrections when they are needed.

Hymes (1974) recommends that for every speech act there be an ethnographic frame work which takes into account the various factors that are involved in speaking. An ethnography of a communicative event is a description of all the factors that are relevant to understanding how that particular communicative event achieves its objectives. For convenience Hymes uses the acronym SPEAKING for the various factors he believes to be relevant. each of these factors will now be considered briefly:

- Setting (S): the setting or scene refers to the time and place in which speech takes place.

- Participants (P): the participants include different combination of speaker-listener, addresser-addressee, or senderreceiver.

- Ends or purposes (E): end refers to the conventionally recognized and expected outcomes of an exchange as well as the personal goals that participants seek to accomplish on a particular occasion. Hymes observes that the purpose of an event from a community standpoint may not be identical to the purposes of those engaged in it. At every level of language individuals can exploit the system for personal and/or social reasons or artistic effect.

Irvine (1974) describes a speech event among the Wolof (a Congo language of Senegambia), the greeting which is a necessary opening to every encounter and in fact can be used as a definition of when an encounter occurs. Relative rank determines who greets whom-it is customary for the lower ranking party to greet the higher ranking party and there is a proverb when two people greet each other, one has shame, the other has glory. However, individuals do not always wish 
to take the higher status because along with prestige goes the obligation to contribute to the support of the low status person.

- Keys (K): by the term key Hymes (1974) means the tone, manner, or sprit in which a particular message is conveyed: light-hearted, serious, precise, pedantic, sarcastic, pompous, etc. the signaling of the key may be non-verbal, by a wink, a smile, gesture, or posture, but may be equally well achieved by conventional units of speech like the aspiration and vowel length used to signal emphasis in English. (Note this factor beside other ones such as Act sequence, instrumentalities, norms, etc. won't be discussed in this study as a limitation of DCT instrument).

Conversation openers (e.g., greeting) are often highly ritualized. The definition proposed here for a greeting illocution simply claims that a speaker communications thereby his awareness that the addressee is present at a potential interactant. The greet act fulfills three functions:

- Speaker wishes hearer to know that speaker has taken cognizance of hearer presence.

- In recognizing hearer's presence via a greet, speaker ratifies hearer social standing with himself and implies a readiness on his part for social interaction.

- It is intended that the greet covers somewhat more ground that the every day term greeting. Further specification is, therefore, possible.

So greeting indicates continuity of personal relation signals the recognition of the other participant as a potential agent in some activity.

A laboratory study of greeting was conducted by Krivonos and Knapp (1975) to discover most frequent verbal and non-verbal associated with them and to investigate whether these behaviors varied according to relationship between interlocutors. 64 college-age men were selected for the study and all greetings collected were videotaped and transcribed. The outcome of the study illustrated the fact that verbal greetings were less common among strangers. While the authors regard greeting as ritualized behavior, Krivonos and Knapp point out that their results could have been specific situation in which they conducted their study.

That this may indeed be the case is suggested by a preliminary study of non-formulaic greetings conducted by Marsha Wesler at the University of Pennsylvania. Basing her findings on an ethnography of her own speech community, Wesler discovered that in interaction among status equals who were well acquainted, conversations were typically initiated not by a formulaic greeting but by a comment or question related to information shared by the participants. While the study was preliminary in nature, a considerable amount of data was collected and analyzed, leading into strong indication that distance and amount of shared knowledge about one another's lives have a strong influence on the frequency with which non-formulaic greetings are used.

Greeting forms are classified in ways other than the verbal-nonverbal dichotomy proposed by Krivonos and Knapp (1975). Halliday (1973) classifies greeting as time-free and time-bound. English hello and its Persian counterpart Salaam are time free and English good morning and its Persian counterpart "Sobh bekheir" are time bound.

Sacks (MS) maintains that there are two important features about greetings. Firstly, they occur at the very beginning of the conversation; secondly, they allow all the speakers a turn, right at the beginning of the conversation.

e.g. Hello there, you two.

Hi.

Hi there ...

There are two major occasions in which a conversation does not start with a greeting. Firstly, conversation between people who do not consider themselves co-conversationalists (for example, strangers). They are not on greeting terms and, therefore, do not exchange a greeting (Coulthard, 1985). The speaker who opens must demonstrate in his first utterance why he is beginning the conversation.

Excuse me, could you tell me the way to ....

Or

Hey. You've dropped your book.

The other conversations which typically do not open with a greeting are telephone conversations. Schegloff argues that although the person who answers the telephone may say "Hello" this is not a greeting, it is the answer to summons from the caller embodied in the ringing of phone. Following this indication that the channel is open there is often a greeting sequence to begin the conversation properly. Sometimes if the answerer simply answers with Hello, there is first a checking sequence to make sure that the caller is talking to the right person.

\section{StATEMENT OF THE StUdy PURPOSE}

The key to understanding Persian social and linguistic purpose lies in an understanding of the dynamics of interpersonal behavior. This is due to intricacies of face-to-face interaction that power is negotiated, alliances are made, action is made and the choices of strategy are set. Greeting exchanges involving the use of names or address terms vary enormously in such terms as who speaks first, what a suitable reply is and even what a variety of language may be employed. In one study Beeman (1986) suggested that the style of spoken Persian is intended to be asymmetrical and restricted. In addition it is stated by Hudson (1996) that some languages provide distinct forms for male and female speakers. This study is to evaluate how rules governing and restricting Persian speech on one hand and on the other hand the differences between speakers' sex may affect speech. The best area for investigating these factors was greeting 
forms, as discussed before this area was considered as one affected both by formulaic and non-formulaic patterns. The present study seeks to find a pattern in greetings terms, used by each sex, in order to explain the reason for such differences.

\section{METHODOLOGY}

\section{1. participants:}

This study was conducted with 40 university students that were including 20 female students and 20 male students studying in Khorasgan University. The purpose for selecting these students was to decrease the negative effect of participants' class difference and to minimize the age difference they were all between 20 and 30 . the number of male/female participants was the same and they were chosen randomly in order to make the study more natural.

\section{2. materials and data:}

Material used to collect the desired data was DCT. Due to the fact that it was hard to tape record all desired situations this instrument was chosen. The corpus used in this study included 12 units of discourse commonly used among the middle class urbane society members in Iran in 10 social settings. The questions and answers were manipulated through observation of some face-to-face encounters. The questionnaire is enclosed (See appendix) and the procedure to make it is explained.

Persian greeting forms discussed in this study could be divided into two major subcategories: time-free and timebound. The following is an attempt at manifesting the major classes of greetings in Persian:

Time- free Persian greetings:

- Salaam( aleikom) [hello, hi]

- Az molaghate shoma khoshbakhtam! [Nice to meet you!]

Time- bound Persian greetings: (daily formal greetings)

- Sobhe (shoma) bekheir. [good morning]

- Zohre (shoma) bekheir. [good noon]

- Asr (shoma) bekheir. [good evening]

When a person meets an acquaintance on the street, the most common form of greeting in Iran is Salaam. It is said in most common (in) formal occasions. More formal greetings are "Sobhe (shoma) bekheir", "Zohre (shoma) bekheir", etc. the formal greeting "az molaghate shoma khoshbakhtam" is normally used when one is introduced to a stranger.

Quite often any greet (except "az molaghate shoma khoshbakhtam") is followed by one of the following questions concerning how the addressee is (which are, as far as possible, arranged hierarchically from the most formal to the least formal; this arrangement is not definite since each form might be used for different functions.):

- Ahvale/ hale jenabe ali chetore? [how is your excellency]

- Ahvale/ hale sharif chetore? [how is your excellency, less formal]

- Hale tan/ shoma chetore? [how are you with plural form of you]

- Halet chetore? [how are you with singular form of you]

- Chetori? [are you ok]

- Halo ruzegar chetore? How is it going?]

What is more interesting fact observed is that Iranian maintenance of politeness is more shown through their use of certain honorifics and phrases in informal conversations. The most common methods of maintaining politeness observed by Salmani-Nodoushan (2007) include the choice of personal pronouns and the use of honorific titles.

Personal pronouns:

The first person singular subject pronoun (I) is sparingly used in Persian face to face interaction. The use of the second person plural subject pronoun shoma is common for when reference is being made to a person of equal or higher rank. The pronoun to is used only in reference to children, intimate friends or servants. The word jenabe aali (your highness, your excellency) is used in place of shoma in reference to status equals or people of higher ranks.

Honorific titles:

The most usual honorifics are khanom (Miss. /Mrs.) and agha (Mr. /Sir). The surname of the individual being addressed will fallow the honorific title. Job titles like doctor, mohandes (engineer) and so are often used together with addressee's surname. When the individual being addressed are of a very higher rank, the job titles are used together with the general honorifics as in khanom mohandes.

Due to the collected data regarding the general greeting terms in Persian the questionnaire was made. This time another factor was taken into consideration, tat of commonality between the youth. Through observation some of the most common forms were chosen and DCT was rearranged. The degree of formality among choices decreases from a-d in order to make data analysis procedure easier.

\section{RESULTS AND DISCUSSION}

A pure contrastive analysis of greeting forms used by Persian males and females shows there are significant differences between them. It seems sex becomes a very important factor contributing to speakers decision how to make an acceptable use of language and avoid failure. Though the chosen settings are the same different answers are made. 
When speech takes place between two friends, though men use more informal and friendly expressions, women put more stress on their feeling and attitudes towards the speaker. It seems the higher degree of intimacy between friends is shown through emotional terms; while in the same situation men tend to use more informal expressions and slangs. Chart 2.

e.g., for male: bi marefat, baba kojaie, etc.

for female : Kheili delam barat tang shode bood.

On the other hand women feel more at ease and have greater solidarity face with their family members and relatives. More interestingly when the addressee is a female relative intimacy increases even if the speaker is a man, though still less than women. Most women's second speech act is about addressee's well-being and his/her family which may be rooted in her interest in "private" subjects. Such subjects suitable for establishing rapport termed by Tannen (1990) as "rapport-speaking" are women's area of interest. While men are more eager to talk about "public" subjects termed as "report-speaking. As it is seen in question no.8, while most men preferred to talk about monetary subjects, women asked about addressee's wellbeing and his/her family (chart.7):

e.g., for male: kar o bar chetore? Wa'ze kar o kasebi chetore? for female: khanom bacheha khooban?

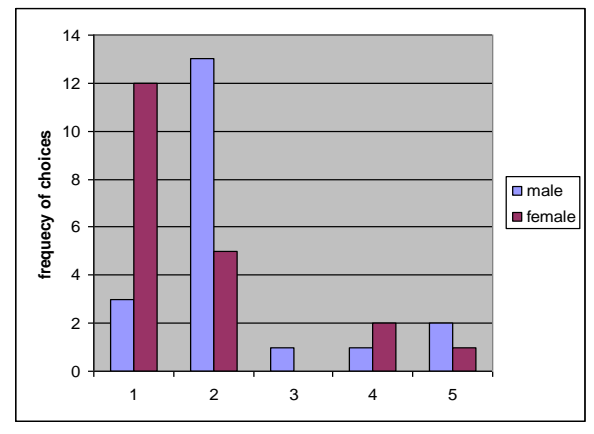

Chart.2

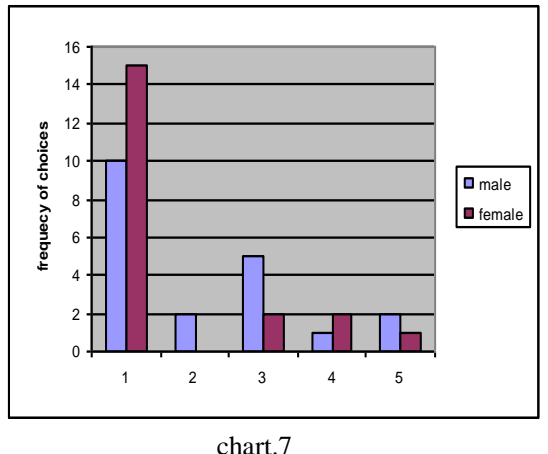

chart.7

As intimacy decreases the difference becomes less significant. While in both cases solidarity face little by little fades away and is replaced by power face, the pattern to respect the addressee's power face differs. It seems women are more likely to use job titles or honorifics when men tend to use the more ritualized expressions. This becomes more tangible if the addressee is a man. (Illustrated in charts no. 8 and 9)

e.g., for male: salaam mitunam chand lahze vaghtetun ra begiram?

for female: salaam aghaye/khanome ......

Salaam ostad.

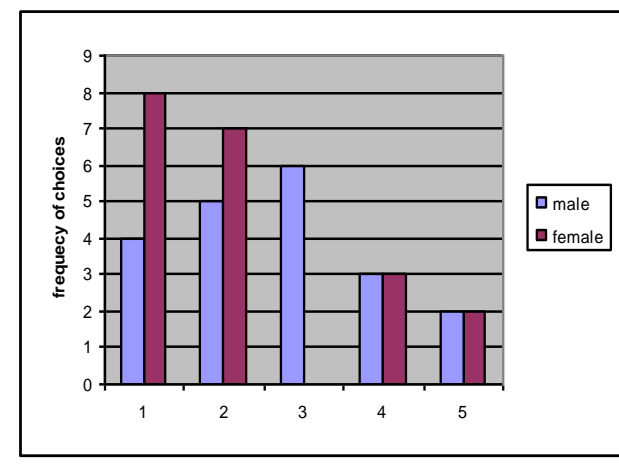

Chart.8

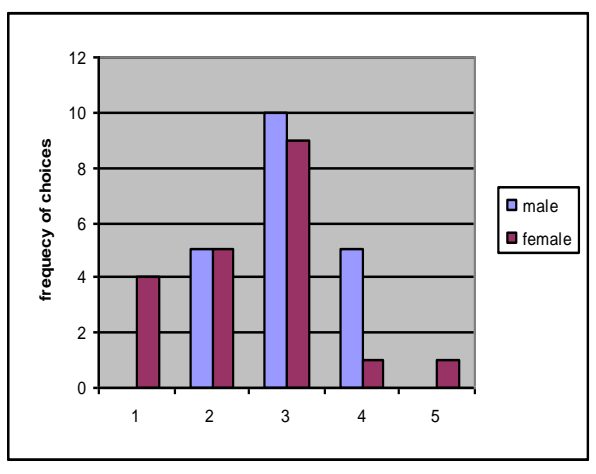

chart.9

In meeting the other sex men seem less informal and women more polite. Male speakers use Shoma (plural you) less frequent but still it is dependent on addressee's status and rank. On the other hand, in terms of using either time-bound or time-free greeting expressions usage (questioned in questions 8-12)though men tend to use time-bound greeting forms more- which may be due to their tendency to use ritualized patterns rather than others-the difference is insignificant. Both sexes prefer to use time-free greeting forms rather than more formal ones.

\section{CONCLUSION}

The present study implies that Persian speakers of different sex vary in their use of linguistic forms. In this study greeting forms were used in as a typical linguistic pattern to compare this supposed difference. Different situations, varying in terms of either greater solidarity or power face on the part of speaker (male or female) were used to 
investigate such difference affirm the hypothesis. Hudson's view discussing how man and omen talk differently in a similar situation is approved in an Iranian context.

Though it is claimed that Persian is highly ritualized, this supposed solid frame work does not apply individual differences. It is quite tangible that Iranian men prefer using more informal expressions and feel a greater power face in comparison to female speakers. Women mostly tend to talk about private subjects and prefer to show how they feel about the subject matter. The reason bringing about such variations may be found in social background of both groups. In a male-dominated society like Iran women have mostly been limited to houses and private life, thus it becomes if they try to be more interested in private topics. While men as leaders of- at least in a miniature society as their housesfeel and own a better power face.

This study could be used as a base for further investigations in sociolinguistics vast arena. Various situations and linguistic forms other than greeting expressions can form a good area of study in which sex is considered as a social variable affecting one's speech.

\section{ApPENDix 1. Charts, Analysis Of Data}

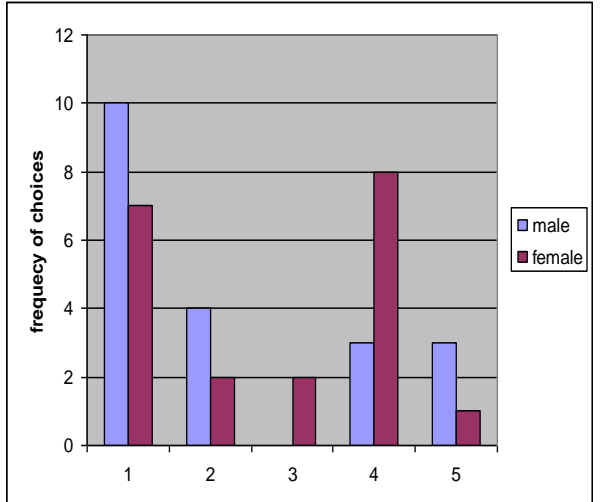

chart_1

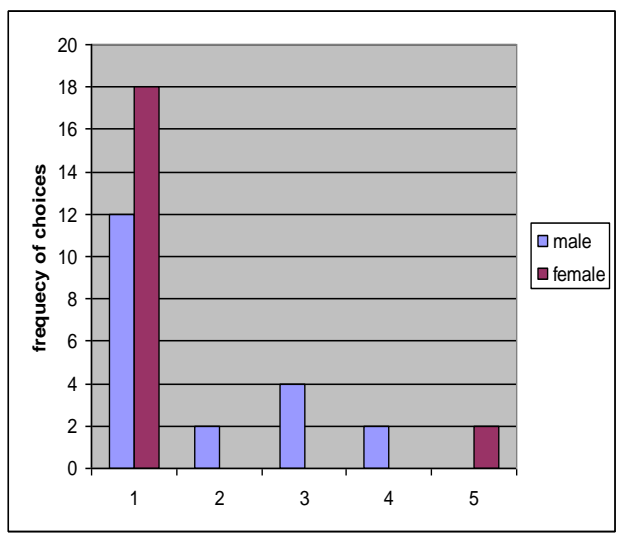

chart_3

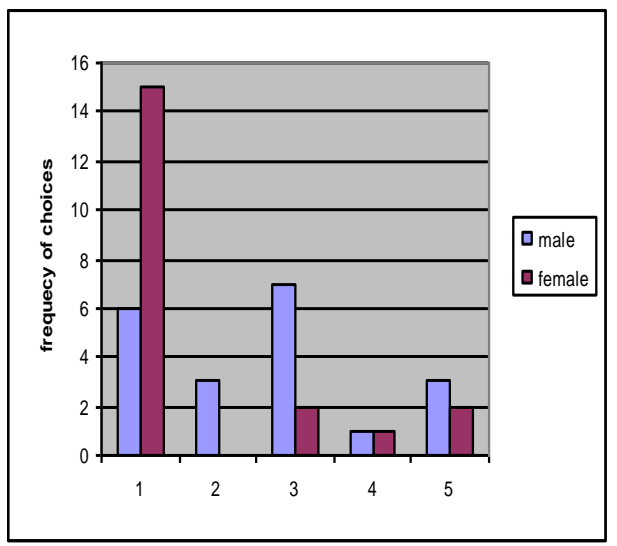

Chrt_5

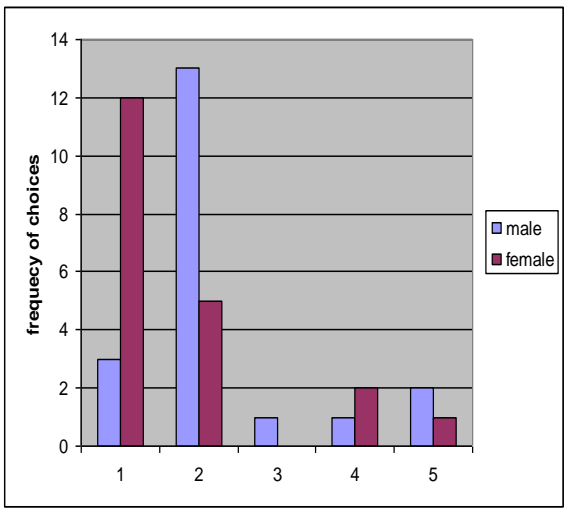

chart_2

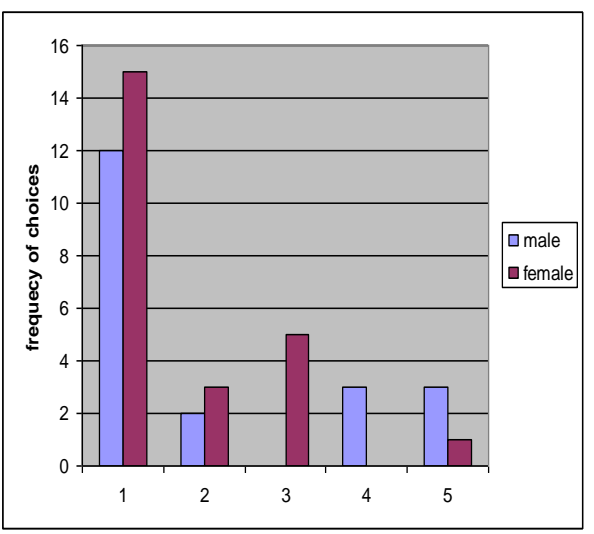

chart_4

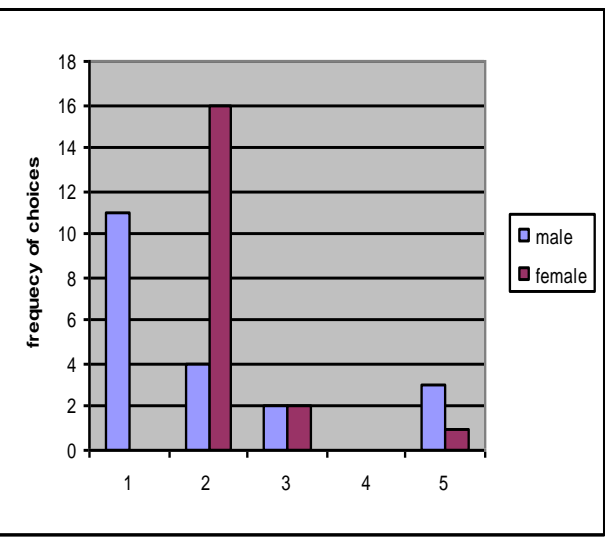

chart_6 


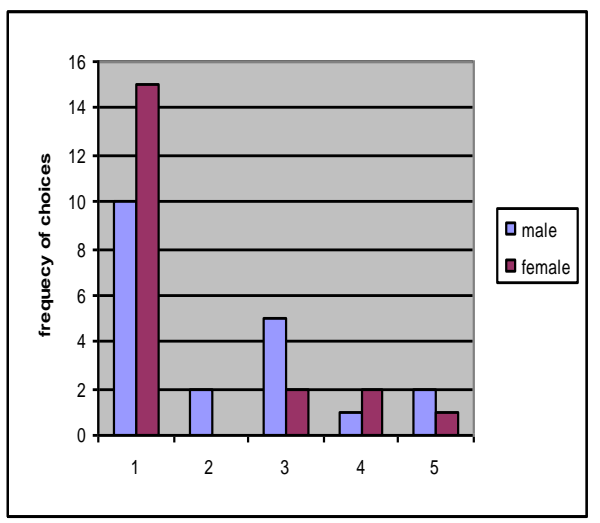

Chart_7

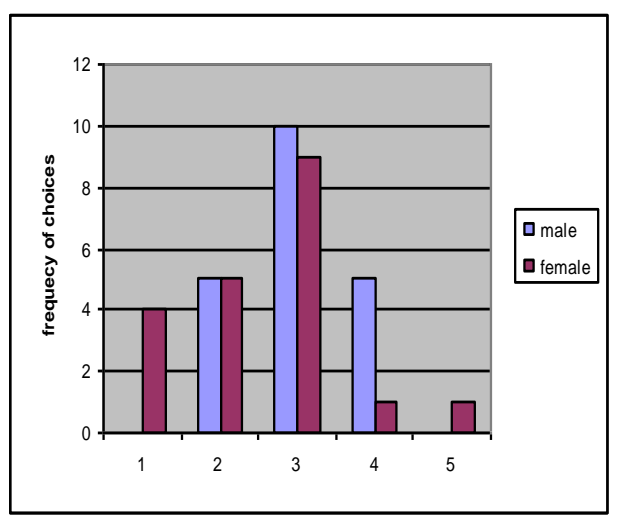

Chart_9

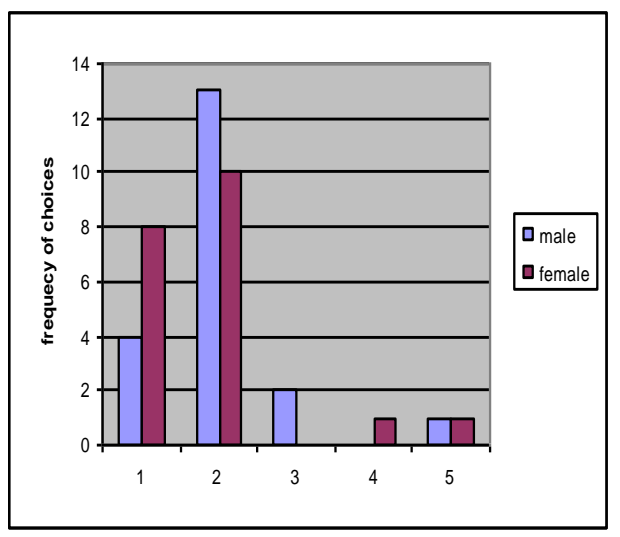

Chart_11

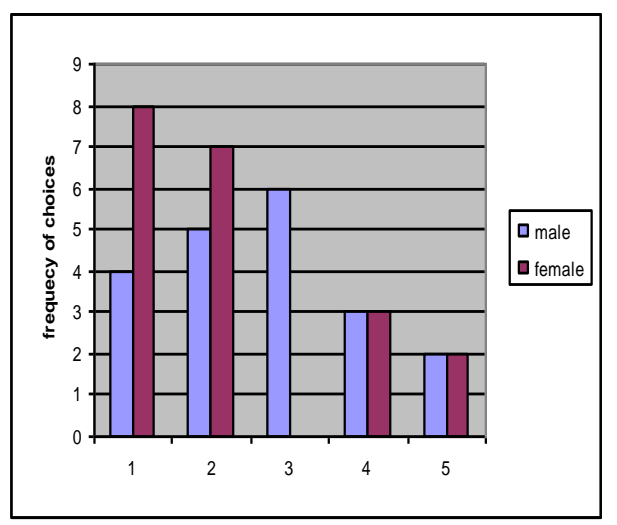

chart_8

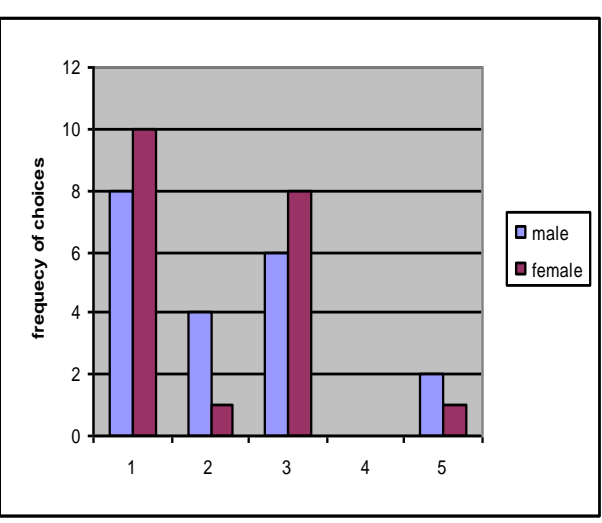

chart_10

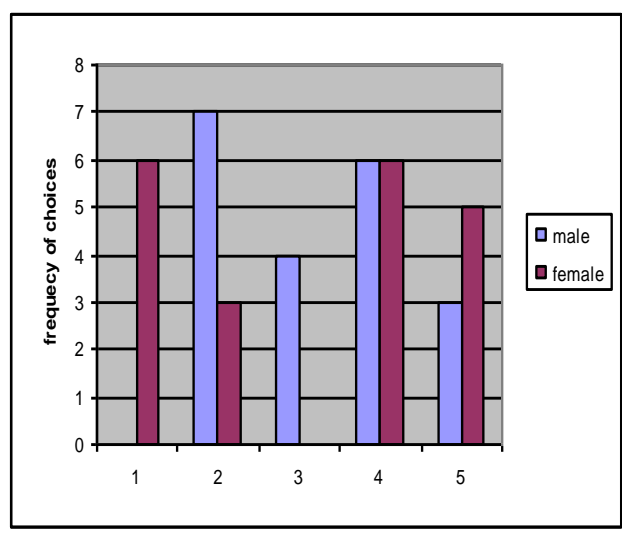

chart_12

APPENDIX.2: QUESTIONNAIRE 


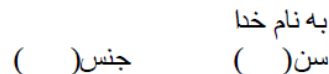

$$
\begin{aligned}
& \text { اكر شما در يكي از شرايط نيل بوديد احتمال اينكه كدام يك از كزينه درئه ها را انتخاب كنيد بيشتز است . }
\end{aligned}
$$

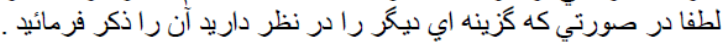

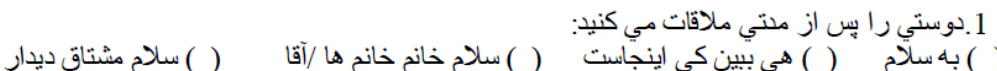

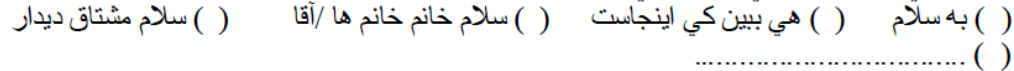

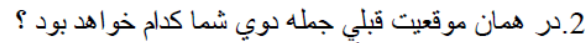

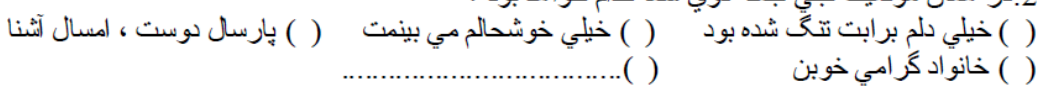

$$
\begin{aligned}
& \text { 3.با يك دوست مال شاقات مي كنيد: }
\end{aligned}
$$

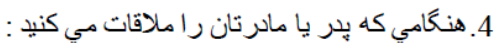

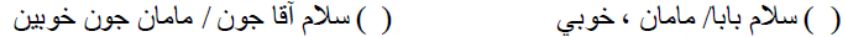

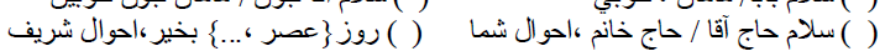

$$
\begin{aligned}
& \text { ………................. ( ) }
\end{aligned}
$$

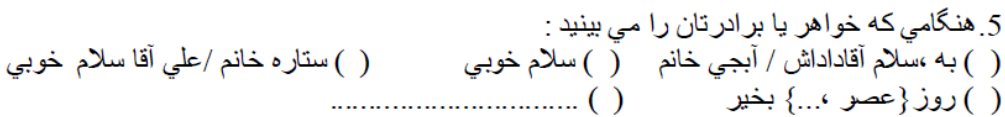

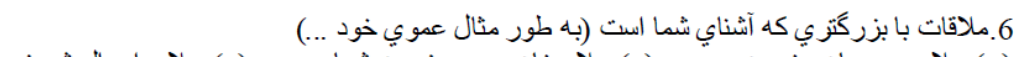

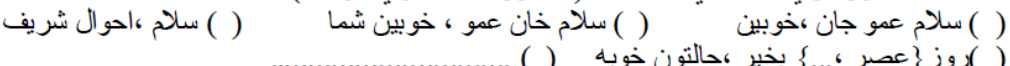

$$
\begin{aligned}
& \text { 7. جمله دوم شما كدام خو اهد بود ؟ خوش }
\end{aligned}
$$

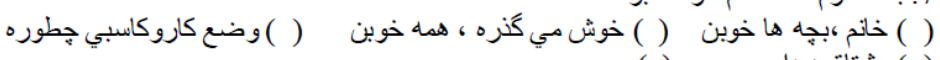

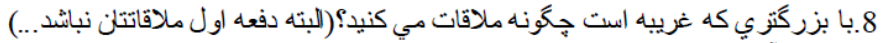

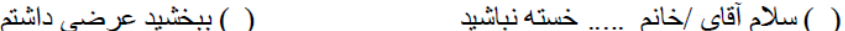

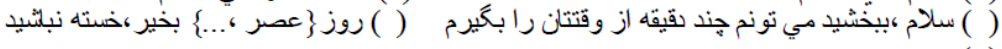

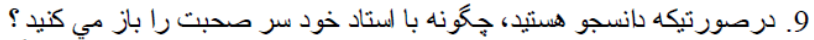

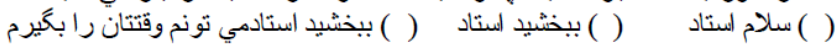

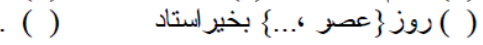

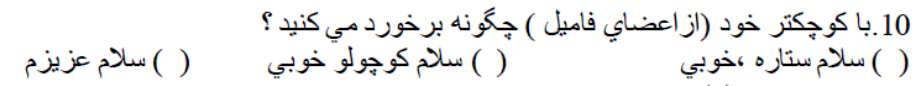

$$
\begin{aligned}
& \text { ( ) }
\end{aligned}
$$

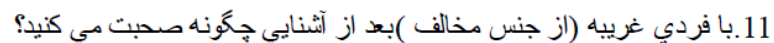

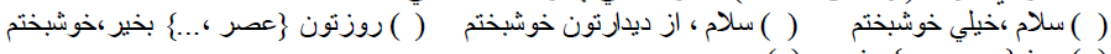

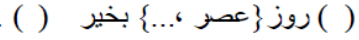

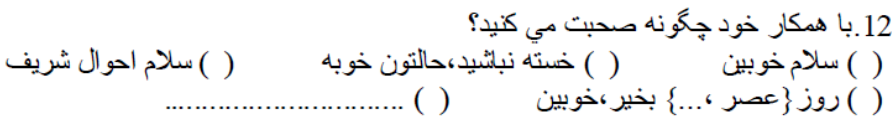

\section{REFERENCES}

[1] Beeman William, O. (1986). Status and power in Iran: Advances in Semiotics. Bloomington: Indiana University Press.

[2] Couthard. M (1985). An Introduction to Discourse Analysis: Applied Linguistics and Language study (2nd Ed.), New York: Longman.

[3] Grice, H. P. (1975). Logic and Conversation in P. Cole and J.L. Morgan (Eds.), Syntax and Semiotics New York: Academic Press, 3; 41-58.

[4] Grimsahw, D.A. (1973). "Rules, social interaction and behavior". TESOL Quarterly. 99-115.

[5] Halliday, M.A.K. (1973). Explorations in the Functions of Language: Exploration in Language Stud. London: Edward Arnold.

[6] Hudson, R.H. (1996). Sociolinguistics. Cambridge: Cambridge University Press, 139-45. 
[7] Hymes, D. (1974). Ways of Speaking in R. Bauman and J. Sherzer (Eds.), Explorations in the ethnography of Speaking. Cambridge: Cambridge University Press, 433-52.

[8] Irvine, J.T. (1974). Strategies of Status Manipulation in the Wolof-greeting in R. Bauman and J. Sherzer (Eds.), Explorations in the ethnography of Speaking. Cambridge: Cambridge University Press, 167-91.

[9] Kirvonos, P. and M. Knapp. (1975). Initiating Communication: What Do You Say When You Say Hello? Central State Speech J., 26: 115-25.

[10] Leech, Geoffrey N. (1983). Principles of Pragmatics. Essex: Longman Group, Ltd.

[11] Malinowski, B. (1923). The Problem of Meaning in Primitive Languages in C.K. Ogdan and I. A Richards, The Meaning of Meaning. London: Rot ledge and Kegan Paul.

[12] Salami-Nodushan, M. A. (2007). Greeting Forms in English and Persian: A Socio-pragmatics Study: Pakistan Journal of Social Science 4 (3): 355-362

[13] Tannen, D. (1990). You just don't understand. NSW: Random House Australia

Salman Dezhara: Born in Iran, Mazandaran, Ramsar city in 1986/5/7. BA in ELT, Chaloos university, Chaloos, year 2009 . MA in ELT, The university of Isfahan, Isfahan, year 2011.

He worked as an English teacher in Shokooh English language institute for 2 years. And is a TOEFL test sessions' supervisor in The university of Isfahan. He got acceptance for publication with the article titled: An Investigation of the Possible Effects of Favored Contexts in Second Language Vo-cabulary Acquisition in CCSE/ELT journal Canada ,2011.

Mr. Salman Dezhara has got his TTC license under the supervision of Kish English institute in year 2008 and passed the TOEFL test with the score 560 in 2008.

Omid Rezaei: Born in Isfahan, Isfahan city, in 20/6/1988. BA in English Translation studies, The university of Isfahan in year 2010. MA in ELT, The university of Isfahan in year 2011.

He worked as an English teacher in reputed English language institutes in Isfahan and TOEFL \& IELTS tutor for 6 years and as TOEFL test sessions supervisor in The university of Isfahan. He got acceptance for publication with the article titled: An Investigation of the Possible Effects of Favored Contexts in Second Language Vocabulary Acquisition In CCSE/ELT journal Canada 2011.

Mr. Omid Rezaei got his TTC license under the supervision of Pouyesh Inc in year 2007. He also passed the IELTS and scored 7.5 in year 2009.

Sajad Davoudi is presently an M.A student in TEFL at The university of Isfahan, Isfahan, Iran. He received his BA in English literature from University of Kashan in 2009. He has over 5 years of teaching experiences at different language institutes. He is currently an English teacher at the ILI language institute. His research interests lie in ESP, EAP, reading strategies, discourse analysis, teacher evaluation, and language teaching.

Reza Soltani Kafrani: was born in 1985. He got his BA in English language translation studies and now is doing his MA in linguistics both in The university of Isfahan. He has published articles in ELT and linguistics related foreign journals.

He has also 2 years of English language teaching record in English learning institutes. 